\title{
Simulation of Petrophysical Parameters of Asmari Reservoir Using SGS Method in Mansuri Oil Field, Southwest of Iran
}

\author{
Hossein Kaviyani Nezhad, Hossein Tabatabaei \\ Department of Oil Engineering, Islamic Azad University, Gachsaran Branch, Gachsaran, Iran \\ Email: Hossein_Tabatabaei@iaug.ac.ir
}

How to cite this paper: Nezhad, H.K. and Tabatabaei, H. (2017) Simulation of Petrophysical Parameters of Asmari Reservoir Using SGS Method in Mansuri Oil Field, Southwest of Iran. Open Journal of Geology, 7, 1188-1199.

https://doi.org/10.4236/ojg.2017.78079

Received: June 2, 2017

Accepted: August 20, 2017

Published: August 23, 2017

Copyright ( 92017 by authors and Scientific Research Publishing Inc. This work is licensed under the Creative Commons Attribution International License (CC BY 4.0).

http://creativecommons.org/licenses/by/4.0/

\section{(c) (i) Open Access}

\begin{abstract}
Porosity and water saturations are the most important petrophysical parameters of hydrocarbon reservoirs that accurate assessment of them in hydrocarbon reservoirs is an effective tool, important and efficient for industry experts, in the context of a comprehensive study of reservoirs and production and management process of reservoir. In this study, using data from five wells of Mansuri oil field, and using the sequential simulation Gaussian method and using Petrel software, the trend of Porosity and water saturation changes in the mentioned field for four zones was simulated. Also the average maps for each zone have been created that results of the simulation parameters in this map showed that highest average porosity is 0.1401 and 0.2756 at least saturation of water is related to zone 1 . Finally result of the simulation indicates the Zone 1 is of the best reservoir Zones.
\end{abstract}

\section{Keywords}

Petrophysical Parameters, SGS Method, Geostatistics, Mansuri Oil Field, Asmari Formation

\section{Introduction}

In general, investigation and simulation of petrophysical properties is one of the main aspects of hydrocarbon reservoirs full studies which is performed in most oil companies. Petrophysical properties of reservoir rock such as lithology, porosity, permeability, net pay thickness and percentage of water and oil saturation obtained from well logs interpretations can be modeled by simulation of the reservoir [1] [2]. It is evident that these characteristics are affected by each well to a certain radius which is defined by the user in the software. By simulation of 
petrophysical parameters, a three-dimensional (3D) view of reservoir properties can be obtained that plays an important role in the development of reservoir flow patterns. Also, by simulation of these parameters, the reservoir potential areas can be identified and used in the development of hydrocarbon oil fields.

Petrophysical modeling is performed by two methods: deterministic and stochastic. SGS method is a stochastic simulation method which implements Geostatistical rules to predict and simulate reservoir parameters in three dimensions of the reservoir. The present study investigates the modeling and the petrophysical parameter of the Asmari formation in Mansuri oil field: South western of Iran (Figure 1).

\section{Methodology}

Modeling software's present a three-dimensional view of all aspects of the reservoir, such as geology and structure of reservoir, fluid dynamics and well [3]. It is considered as an advanced management tool that facilitates maximum production from the reservoir [4]. These software's also help users in designing maps, creating petrophysical properties models, simulating fluid flow in reservoir, placing and designing new wells and reservoir management [5].

One of the most efficient methods to estimate and simulate petrophysical parameters contained in these software's is SGS method that depends on wells and geophysical data [6].

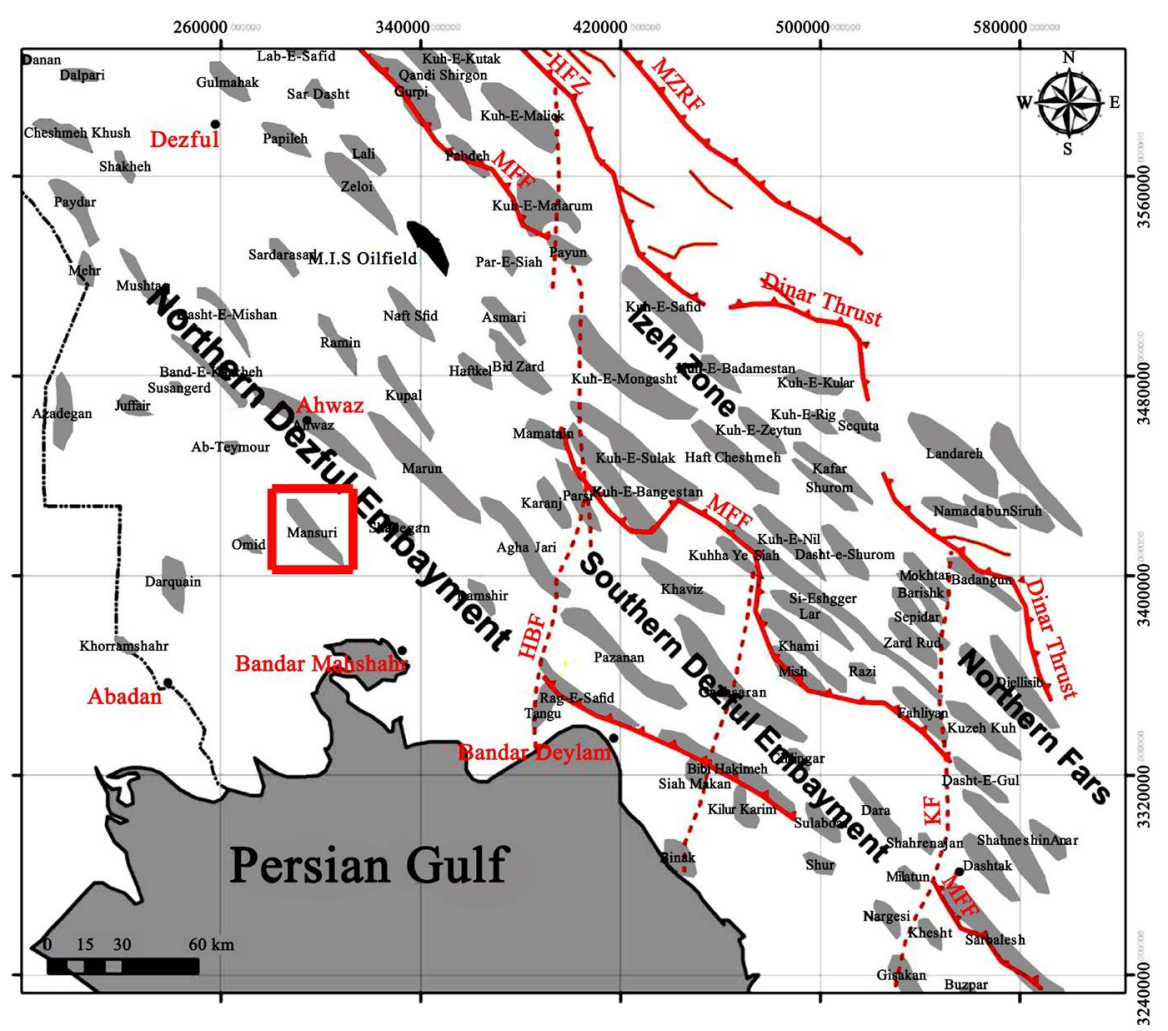

Figure 1. Located of Mansuri oil field in Dezful embayment, near the other oil fields, Southwest of Iran. 


\section{Reservoir Geometry and Gridding}

\section{Structural Modeling of the Reservoir}

Typically, structural modeling of reservoir, is the starting point of the reservoir modeling [7]. In this part, the reservoir structure is modeled with geological properties, including tectonic characteristics and faults [8]. Also, cross section from different parts of model can be obtained to examine reservoir layers variations with thickness change and etc. Investigation of these variations allows other phases of the reservoir interpretation to be commented on. A grid model of the reservoir includes a three-dimensional cells, each of these cells contains an average of petrophysical parameters. In building the reservoir model and to obtain an accurate estimation of reservoir volume, division of the reservoir to small cells is necessary [9]. Size, direction and shape of each of the cells depend on the size of reservoir, the amount of known data from the reservoir and the direction and orientation of reservoir fractures, respectively.

Corner point gridding of the reservoir: the cells in this gridding method are very flexible and can easily show faulting effects. The other advantage of these cells is the ability to create the reservoir flow simulation cells. Generally, these cells are more suitable for geological features and because of this advantage, in this study, these cells were used for gridding of Asmari reservoir. But in the layering of cells proportional method was used in which the number of cell layers was considered constant in the reservoir and their top and bottom surfaces was considered parallel to the top and bottom surfaces of the reservoir layer. The size of each cell was $1 \times 120 \times 120$ meters.

\section{Data Analysis}

After data up scaling, two fundamental conditions in Geostatistical calculations are: first, the data has a normal distribution and second, the data shows no trend. The spatial relationship between the values of a quantity in taken samples population can be expressed in the form of spatial structure [10]. These spatial structures are in fact the experimental variograms which are defined in three directions for petrophysical data of wells. According to the variograms, petrophysical parameters of each cell in the reservoir are valued in proportion to its distance from the wells, and finally the distribution of each parameter is obtained in the reservoir.

\section{Data up Scaling}

Petrophysical data are in the form of logging data in the well trajectory. Before the simulation, the parameters must be averaged in the cell size defined in the reservoir. This gives a value for different parameters for each cell. There are different methods to calculate the average of parameters, numerical averaging method is the best one due to static nature of porosity and water saturation. The formula of numerical averaging method is as follow: 


$$
K_{A}=\frac{1}{N} \sum_{i=1}^{N} K_{i}
$$

where $K_{A}$ is the average of petrophysical parameter $K, K_{i}$ is the value of parameter $\mathrm{K}$ in the position $i$ and $N$ is the number of samples. In Mansuri oil field using the 5 wells drilled in different locations of the south area of reservoir (Figure 2) with the logging data, the porosity and water saturation data up scaling operation has been performed using the above method. Part Major of production of this oil field, belong to the south section of area; accordingly, we selected the wells from the south and southwest of Mansuri oil field.

\section{Data Transform}

In order to implement stochastic methods, existing trends in the data which might be created due to geological characteristic of the region, must be identified and removed. In order to remove the trends in the data, first, the data must be normalized and then kurtosis of the normal distribution must be increased as much as possible until a range of data which is used accumulate largely around the mean data. Then, no trend remains in the kurtosis of the data. One of other

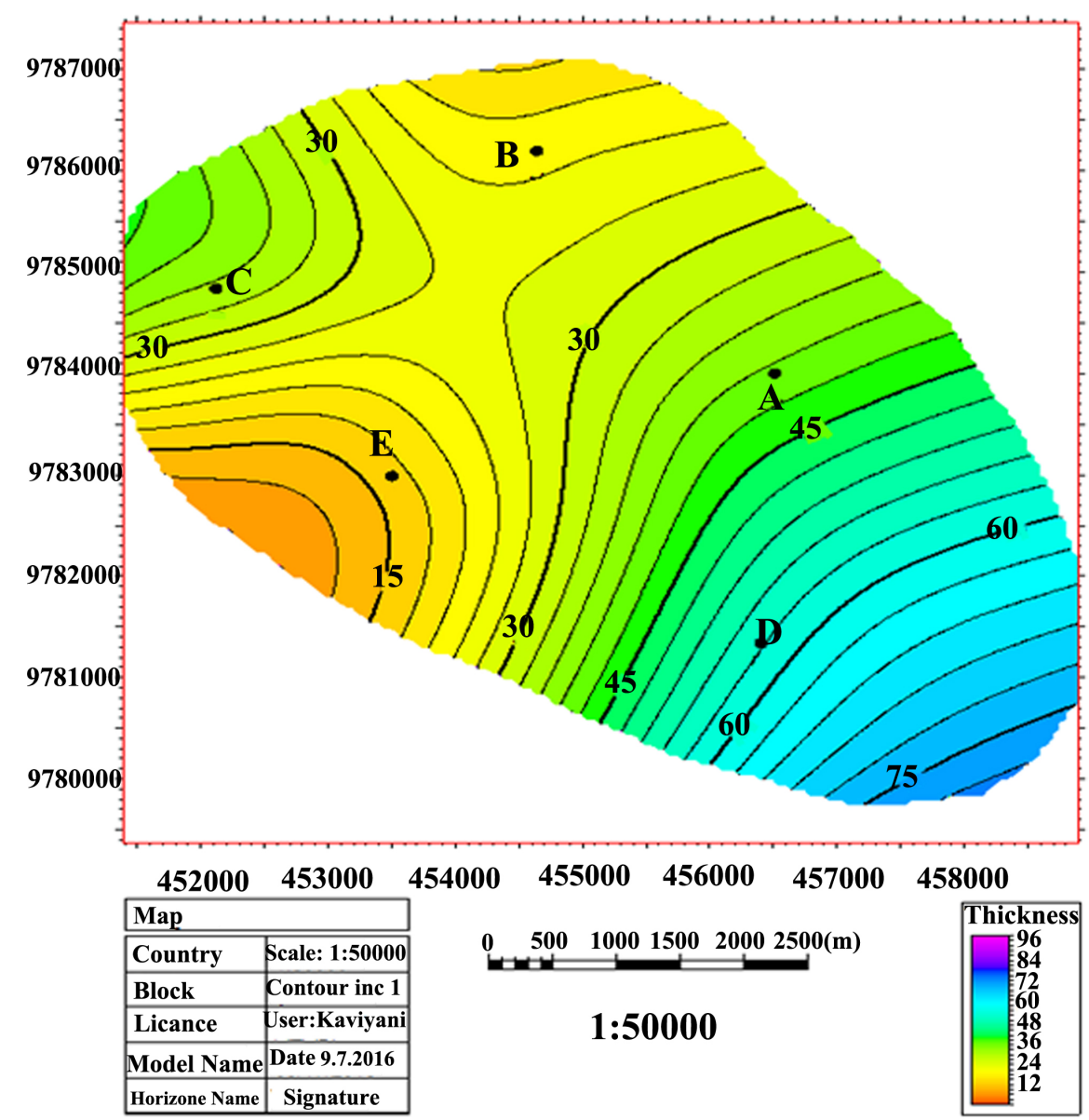

Figure 2. Situation of different wells in Mansuri oil field. A (Well No. 4), B (Well No. 5), C (Well No. 7), D (Well No. 11), E (Well No. 16). 
conditions to implement stochastic method for simulation of petrophysical parameters is to have standard normal distribution of the data. In normal distribution of the data, mean is equal to zero, standard deviation is equal to 1 and their distribution diagram is a Gaussian distribution. Qualitatively, normal distribution of data can be detected using formation statistical tools such as Histograms, skewness and kurtosis of data distribution, based on which the porosity and water saturation data were normalized (Figure 3 ).

\section{Variograms Calculation for the Data}

In Geostatistics using the data of a quantity in a known coordination, it is possible to estimate the value of the quantity in a different spot with a known coordinates located within the range of the spatial structure [11]. The variograms for the data express the difference of a parameter from known locations based on the distance (Lag) from the point. Using the variograms model, the value of the parameter is estimated at unknown locations. The spatial structure in statistical computations is the same as experimental variograms defined for data with normal distribution and no Defined trend [12]. The formula for the variograms is as follows:

$$
(h)=\frac{1}{2 N(h)} \sum_{i=1}^{i=N(h)}\left(X_{i}-X_{i+h}\right)^{2}
$$

where $h$ is variograms value, $N(h)$ is the number of data pairs and $x_{i}-x_{i}+h$ is beginning and end of data pair $i$.

In general, the variograms in which one axis is variance and the other one is the distance, shows the variability of data versus the distance [12]. The more re-

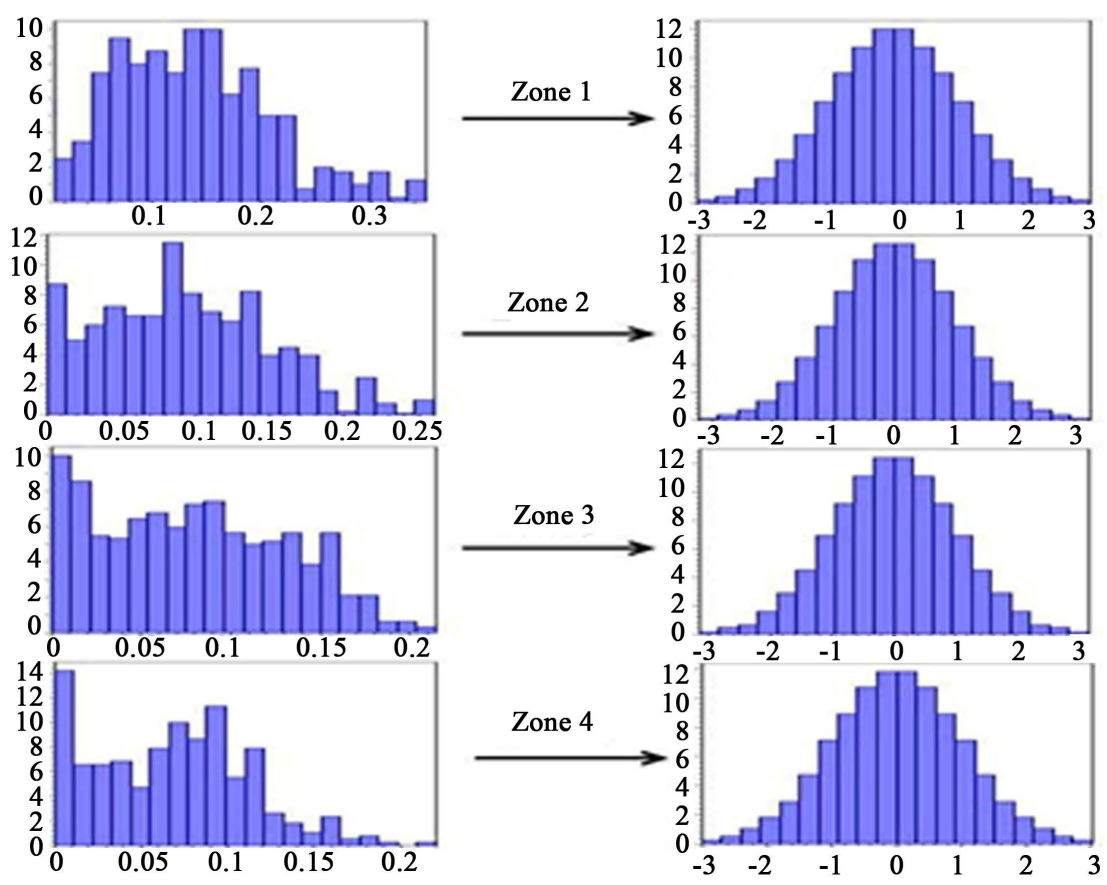

Figure 3. Normalized of porosity data and histograms of them. 
gular and symmetrical arrangement of wells and more homogeneous reservoir, the less variance of the estimation of petrophysical parameters of reservoir rock. Figure 4 shows porosity and water saturation variograms for each zone separately in $\mathrm{Z}$ direction which is the most important direction of the variograms due to the high density of data.

Selection of horizontal directions of the variogram is performed based on the acoustic impedance map which reflects the homogeneity and the heterogeneity of reservoir. So that the major axis of the variogram $(X)$ is in the more homogeneous (low variance) direction and its length is half length of the reservoir and minor axis $(Y)$ is perpendicular to this axis and its length is equal to half the width of the reservoir (Figure 5). Also, lags in the variogram in the horizontal direction is the distance between two consecutive known points or the distance between two consecutive wells and in the vertical direction, variogram is equal to the thickness of the cell.

\section{Results and Discussion}

Having defined the mentioned condition, the petrophysical data has been simulated by SGS method which was presented in separate SGS models for each of the fore zones (Table 1). The models allow to investigate variations of porosity and water saturation in both the vertical and the horizontal direction. The resultant

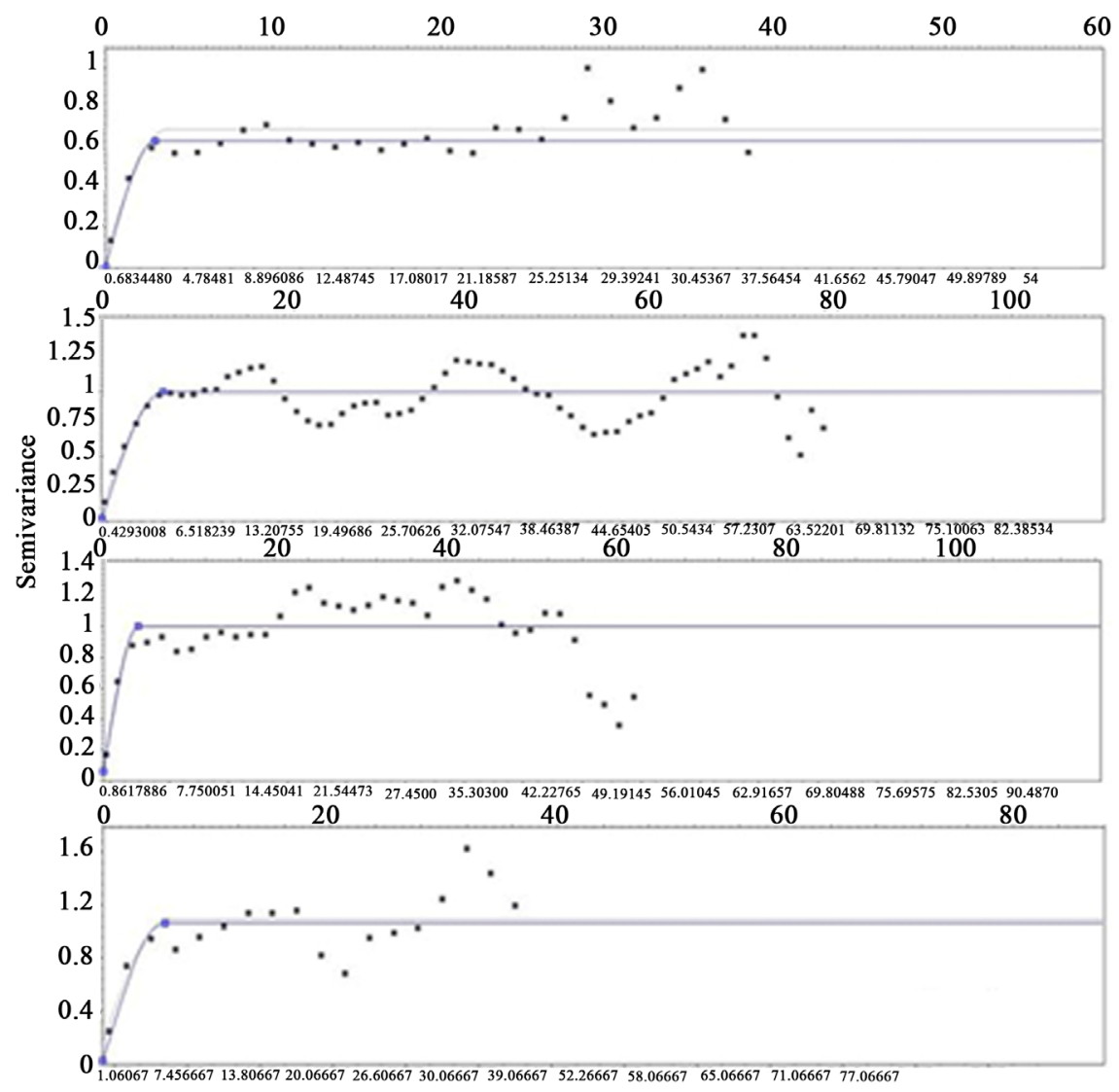

Figure 4. The variogram of neutron and porosity data for 4 zone, in vertical $(Z)$ axes. 


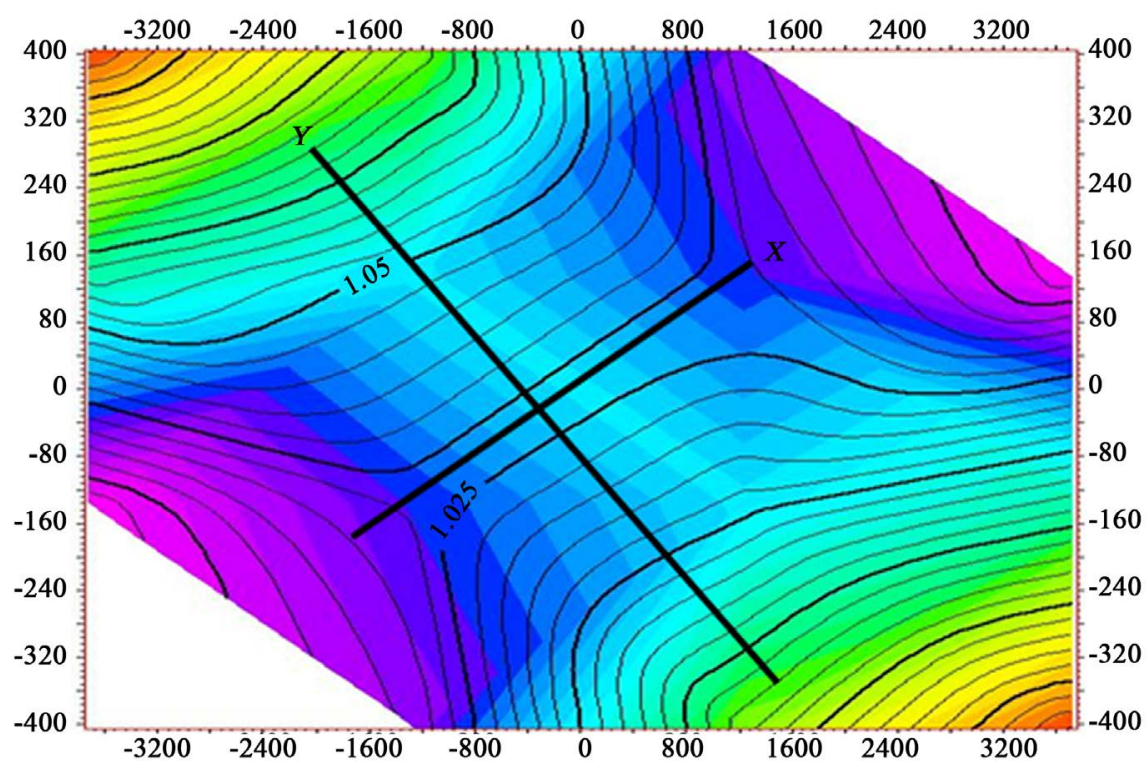

Figure 5. Variogram is performed based on the acoustic impedance map which reflects the homogeneity $(X)$ and the heterogeneity $(Y)$ of reservoir.

Table 1. Calculated amounts of porosity and water saturation for 4 zones.

\begin{tabular}{ccc}
\hline Permeability & Porosity & Zone \\
\hline 0.2756 & 0.1401 & Zone 1 \\
0.4667 & 0.0970 & Zone 2 \\
0.3915 & 0.0771 & Zone 3 \\
0.6015 & 0.0642 & Zone 4 \\
\hline
\end{tabular}

integrated model of all layers has also been built. Generally, the porosity and water saturation variation maps shows that in porosity values distribution map, its maximum value starts at Southeast of the field, passing through the center it ends at Northwest of the field (Figure 6) which is the effect of Paleofacies which improves the porosity of the region due to different lithology (Figure 7). Base in Geolog 6.7.1, and using for NPHI-RHOB plot, the lithological composition of Asmari formation in this area, was recognize. The main of this lithology is limestone (Figure 8). The computation data analysis by help of SGS software 3D modeling of the average of the porosity for all zone were made. In Figure 9, variation maps shows that in porosity value for Zone 1.

Water saturation model that shows the value of water saturation in oil zones, is mainly of the irreducible water saturation, which is affected by the reservoir capillary pressure, relative permeability and porosity. To build water saturation model in the reservoir co-kriging of reservoir porosity has been used as a secondary parameter. In this model, maximum water saturation belongs to North and Northwest of the field (Figure 10).

To assess the model accuracy, the results should be compared with actual data in wells (validation) (Figure 11). The closer model results to the actual data, the 


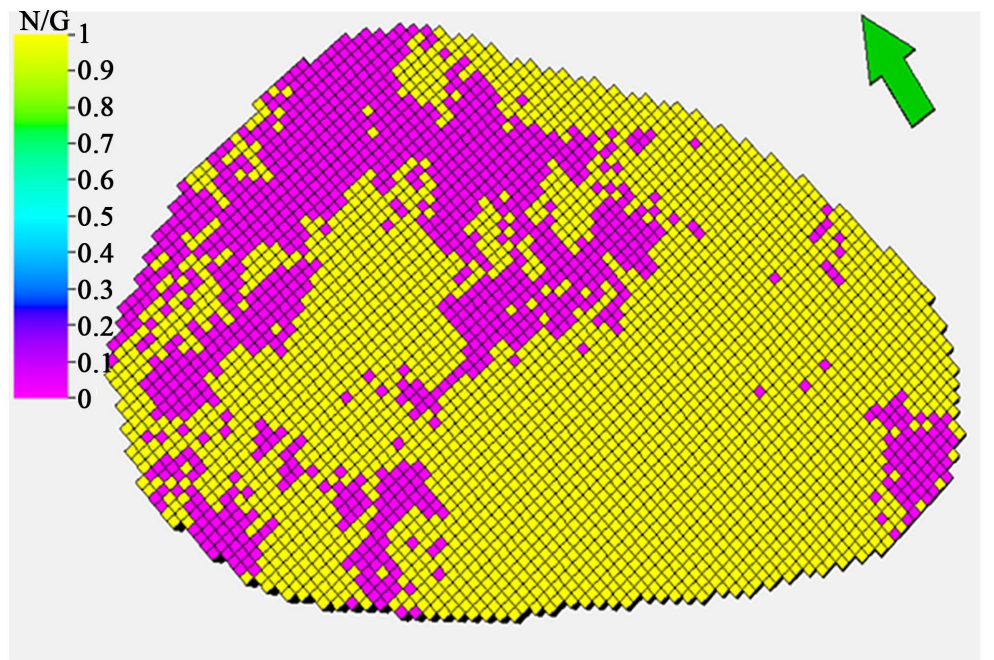

Figure 6. Modeling of changes in reservoirs properties in Mansuri oil field, Asmari reservoir. Its maximum value starts at Southeast of the field.

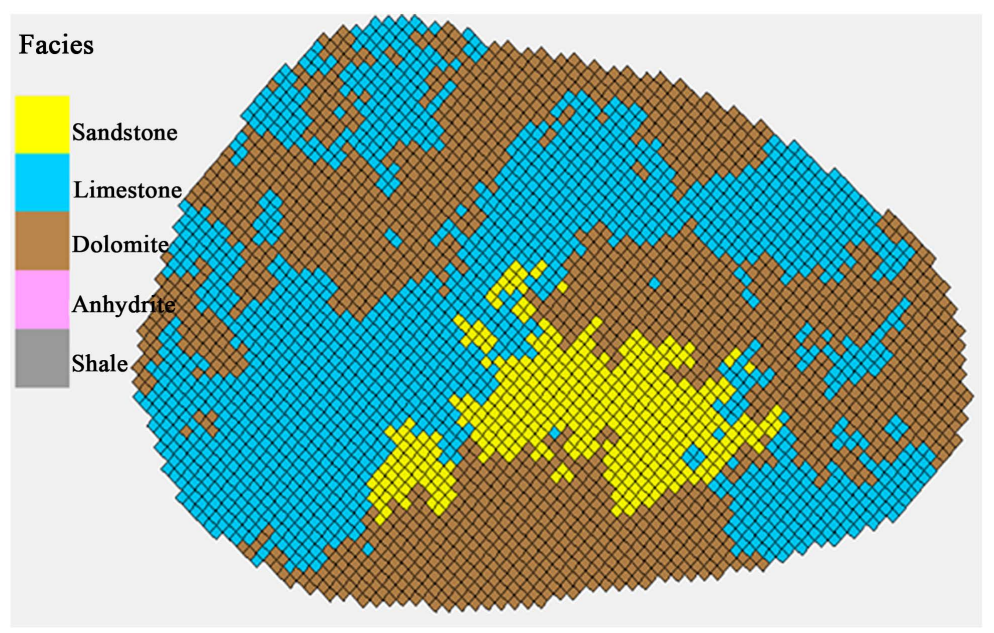

Figure 7. Term of lithological composition and change in facies of Asmari formation in zone 1, Mansuri oil field.

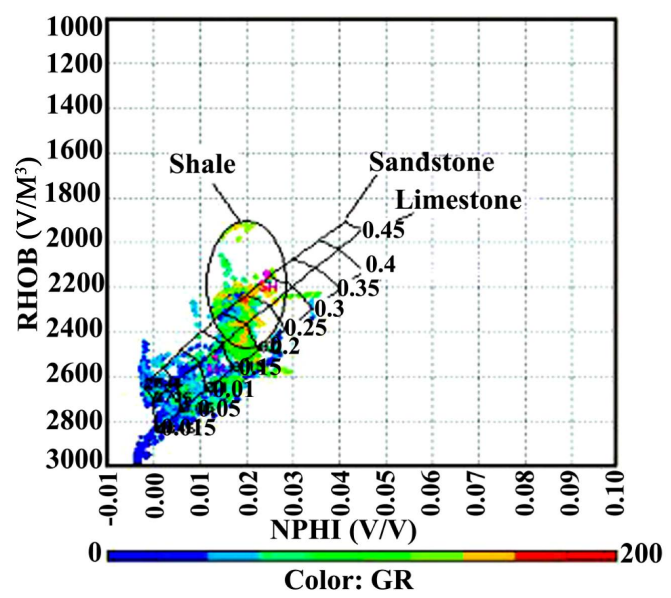

Figure 8. Plot of RHO-NPHI, using for recognition of lithological composition in Asmari Formation. 


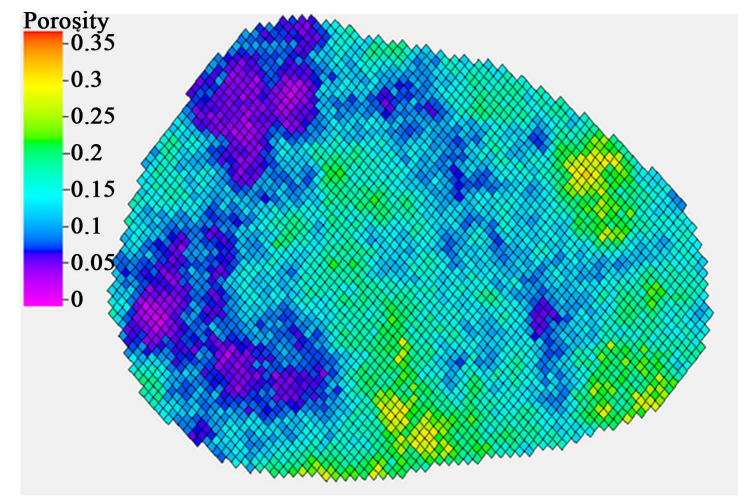

Figure 9. Model of distribution of porosity for zone 1. Maximum of porosity belongs to South and Southeast of the field.

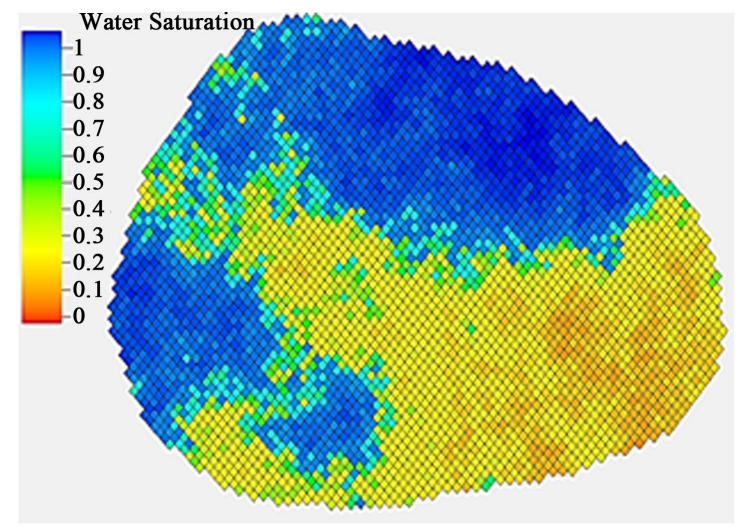

Figure 10. Model of distribution of water saturation in zone 1. Maximum water saturation belongs to North and Northwest of the field.

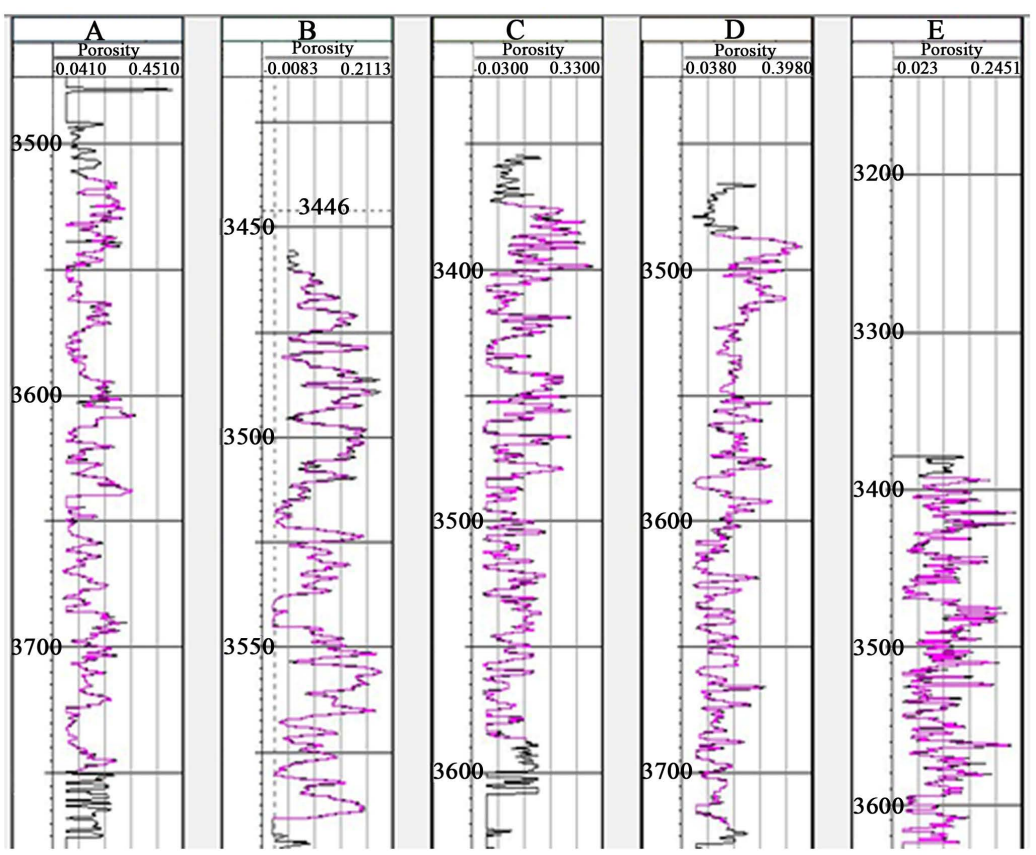

Figure 11. Validation and correlation between real and estimated data of some wells in Mansuri oil field. 
more accurate will be the developed model which in the Asmari model very good agreement is observed between the model results and data for porosity (Figure 12) and water saturation (Figure 13).

Finally, to identify potential areas of the reservoir, applying cut off limits for two parameters of porosity and water saturation, reservoir and non-reservoir areas model has been obtained.

Cut off limits for porosity and water saturation were considered $5 \%$ and $30 \%$, respectively. This means that according to the production characteristics, reservoir areas should be above $5 \%$ of porosity and below $30 \%$ of water saturation. The model shows that except the southern, central and a part of Southwestern areas, the field has suitable reservoir characteristic which can be taken into account in development plans.

\section{Conclusion}

In the present study, the SGS method, has been implemented to produce a 3D

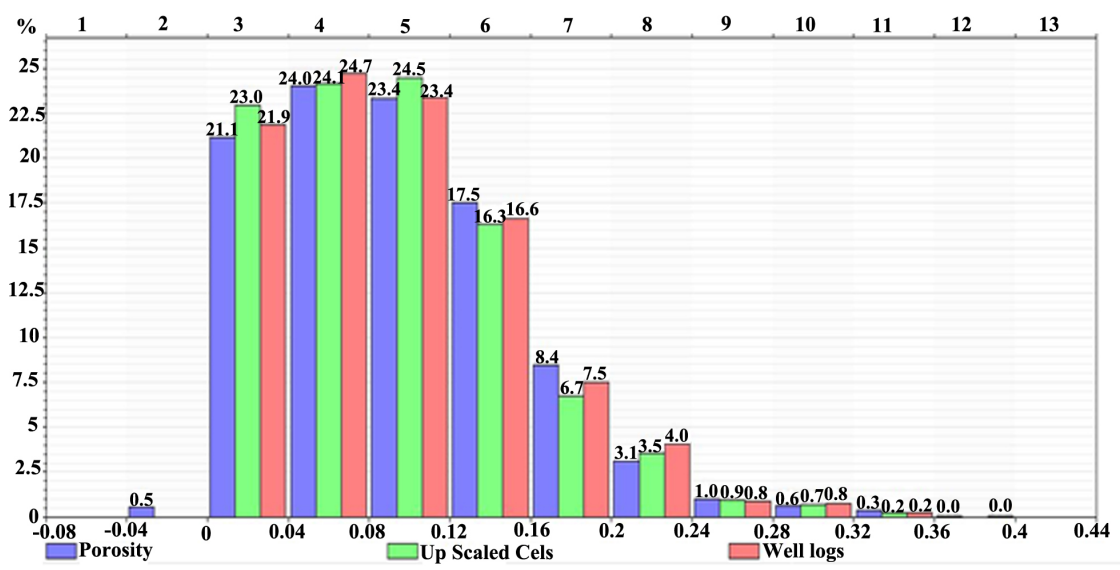

Figure 12. The result of validation for porosity in Mansuri oil field base in histogram, well logging data and SGS modeling.

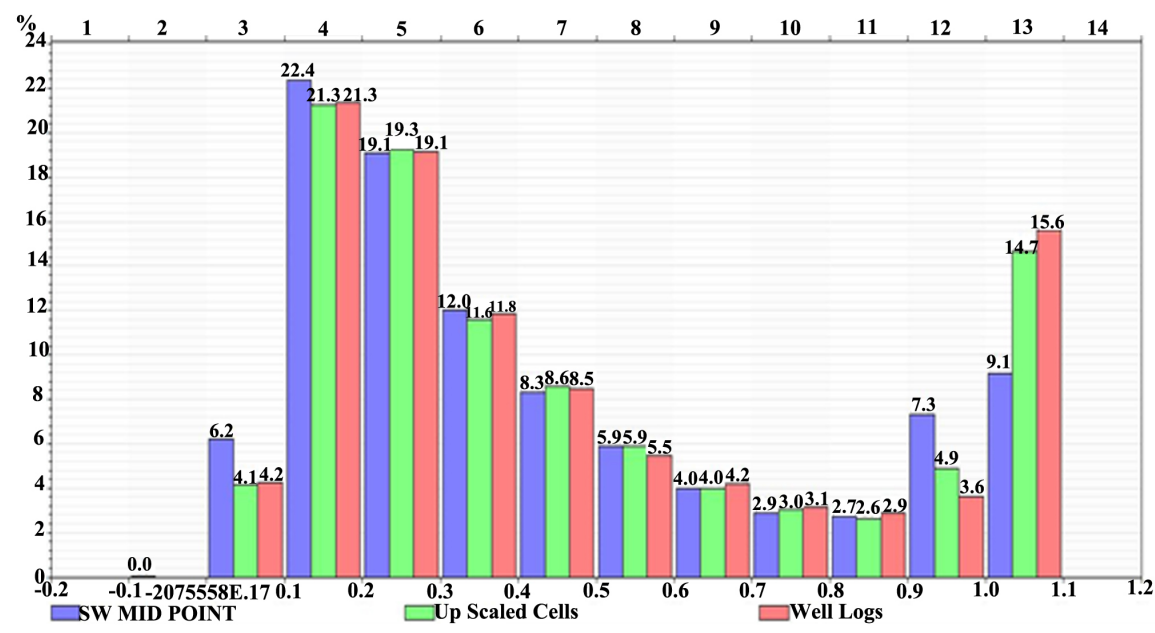

Figure 13. The result of validation for water saturation in Mansuri oil field base in histogram, well logging data and SGS modeling. 
petrophysical model of Asmari reservoir of Mansuri oil field (located in Southwestern of Iran). SGS method is an efficient method to estimate and simulate petrophysical parameters. The petrophysical properties i.e. porosity and water saturation have been used for petrophysical modeling. The data from 5 wells located in Southern section of the field has been used, therefore the results of simulation are limited to Southern area of the studied field. The software, Petrel has been used in this study, which covered whole reservoir simulation stages from the interpretation of seismic data to building static and dynamic models of hydrocarbon reservoirs. Due to high lithology heterogeneity in vertical or well drilling direction in Mansuri oil field, petrophysical parameters change in this direction while because of lithology continuity, variations of these parameters in the horizontal direction are less than those of vertical direction. In data analysis, the more organized well pattern and symmetrical distribution, the less estimation variance for reservoir rock parameters and more accurate spatial structure for the data. The maximum value of porosity starts from south and decreases to the north of the studied section. Also, the maximum amount of water saturation can be found in the north of the section. Zone 1 is the best reservoir section which has the highest value for the porosity and the lowest amount of water saturation. Zone 4 has the lowest reservoir value because of poor porosity and high water saturation. The results of models verification showed that estimation and simulation of the porosity and water saturation using sequential Gaussian Simulation Method (GSM) has been properly performed. Finally, to identify potential areas of the reservoir, $5 \%$ and $30 \%$ were applied as cut off limits for porosity and water saturation, respectively. The resulting model showed that the southern part possesses better reservoir characteristics comparing to other parts of the studied section.

\section{Acknowledgements}

We would like to express our sincere thanks to the Department of Oil Engineering, Gachsaran Branch, Islamic Azad University, and all our colleagues for critical discussions and support. Thanks also to the anonymous referees for all their gracious and critical points.

\section{References}

[1] Doveton, J.H. (1994) Geologic Log Analysis Using Computer Methods: Computer Application in Geology. American Association of Petroleum Geologists, Tulsa.

[2] Yeten, B. and Gumrah, F. (2000) The Use of Fractal Neural Networks Artificial Geostatistics for Carbonate Reservoir Characterization. Journal of Transport in Porous Media, 41, 173-195. https://doi.org/10.1023/A:1006725709303

[3] Robinson, A. and Griffiths, P. (2008) The Future of Geological Modeling in Hydrocarbon Development. 2th Ed., Geological Society.

[4] Clayton, V. (2002) Geostatistical Reservoir Modeling. Oxford University Press, New York.

[5] Kaufmman, O. and Martin, T. (2008) 3D Geological Modeling from Boreholes, 
Cross-Sections and Geological Maps, Application over Former Natural Gas Storages in Coal Mines. Journal of Computers \& Geosciences, 34, 278-290. https://doi.org/10.1016/j.cageo.2007.09.005

[6] Eisinger, C.L. and Jensen, J.L. (2009) Data Integration, Petrophysics, and Geomodelling. University of Calgary, Calgary.

[7] Diggle, P.J. and Ribeiro, P.J. (2007) Model-Based Geostatistics. Springer Science, Library of Congress.

[8] Holden, L., Mostad, P., Nielsen, B.F., Gjered, J., Townsend, C. and Ottesen, S. (2003) Stochastic Structural Modeling. Journal of Mathematical Geology, 35, 899914. https://doi.org/10.1023/B:MATG.0000011584.51162.69

[9] Randen, T. (2008) Mathematical Methods and Modelling in Hydrocarbon Exploration and Production (Mathematics in Industry). Schlumberger Stavanger Research.

[10] Bahar, A. and Kelkar, M. (2000) Journey from Well Logs/Cores to Integrated Geological and Petrophysical Properties Simulation: A Methodology and Application. SPE Paper 39565, First Presented at the SPE India Oil and Gas Conference and Exhibition, New Delhi, India.

[11] Etminan, A.H. and Seifi, A. (2008) An Improved Model for Geostatistical Simulation of Fracture Parameters and Their Effects on Static and Dynamic Models. International Conference on Engineering Optimization, Rio de Janeiro, Brazil, 1-5 June 2008. https://doi.org/10.2174/1874834100801010047

[12] Amanipoor, H., Ghafoori, M. and Lashkaripour, G.R. (2013) The Application of Geostatistical Methods to Prepare the 3D Petrophysical Model of Oil Reservoir. Open Journal of Geology, 3, 7-18.

Submit or recommend next manuscript to SCIRP and we will provide best service for you:

Accepting pre-submission inquiries through Email, Facebook, LinkedIn, Twitter, etc. A wide selection of journals (inclusive of 9 subjects, more than 200 journals)

Providing 24-hour high-quality service

User-friendly online submission system

Fair and swift peer-review system

Efficient typesetting and proofreading procedure

Display of the result of downloads and visits, as well as the number of cited articles

Maximum dissemination of your research work

Submit your manuscript at: http://papersubmission.scirp.org/

Or contact ojg@scirp.org 